\title{
Vendace (Coregonus albula) in Lake Inari - what has changed in 50 years?
}

\author{
Erno Salonen
}

Natural Resources Institute Finland (Luke), Saarikoskentie 8, Fl-99870 Inari, Finland (e-mail: erno. salonen@luke.fi)

Received 5 Oct. 2020, final version received 17 June 2021, accepted 18 Mar. 2021

Salonen, E. 2021: Vendace (Coregonus albula) in Lake Inari - what has changed in 50 years? - Ann. Zool. Fennici 58: 243-253.

Lake Inari is a subarctic, oligotrophic, regulated lake in northern Finland, connected via the Paatsjoki (Pasvik) River to the Arctic Ocean. A new coregonid species, the vendace (Coregonus albula), was introduced into the watershed in the 1960s and gradually established a population in the lake becoming part of its ecosystem. The annual vendace catch in 1989 reached 300 tonnes, while during the following 25 years the vendace catches declined stabilizing at a very low level. Vendace introduction radically changed the fishing practices within a short time, and its population became firmly established in the lake. It benefited both fisheries and predatory fishes, especially salmonids. The vendace year-class strength varied greatly between 1983 and 2019. According to winter seine CPUE data, the strongest year-classes were up to 100 times greater than the weakest ones. Winter seine CPUE of one-year-old fish correlated positively with catches in the coming years. The growth data for the period 2015-2021 revealed a decrease in the youngest vendace age-groups.

\section{Introduction}

The vendace (Coregonus albula) is not native to Lake Inari or the Paatsjoki (Pasvik) watershed. A native coregonid is the dwarf densely-rakered European whitefish (reeska in Finnish) (Coregonus lavaretus), which is similar to the vendace both biologically and ecologically. Its gillraker count, however, is between 30 and 40, while the vendace gillraker count is over 40 (Salonen 1992, and author's own unpubl. data). In general, an introduced or invasive species that became established in a new environment may, even long after establishment, undergo substantial and unpredictable population fluctuations, including also boom-and-bust cycles (Williamson 1996).
Such fluctuations were observed in the invasive vendace population in Lake Inari (Finland) and further downstream in the Paatsjoki watershed (Norway and Russia) (Salonen et al. 2007).

In 1956, some vendace larvae escaped accidentally from an Inari fish farm into the Juutua River, which flows to nearby Lake Inari. In 1964-1966, vendace was introduced into nearby Alajärvi (Fig. 1). According to local accounts (J. Kyrö pers. comm.), newly hatched vendace larvae were also stocked directly into the Ivalojoki. The distance from Alajärvi along the Ivalojoki to Lake Inari is about $30 \mathrm{~km}$. In some way, perhaps by active swimming or drifting with the current down the river, sufficient amount of larvae managed to enter the southernmost part of 


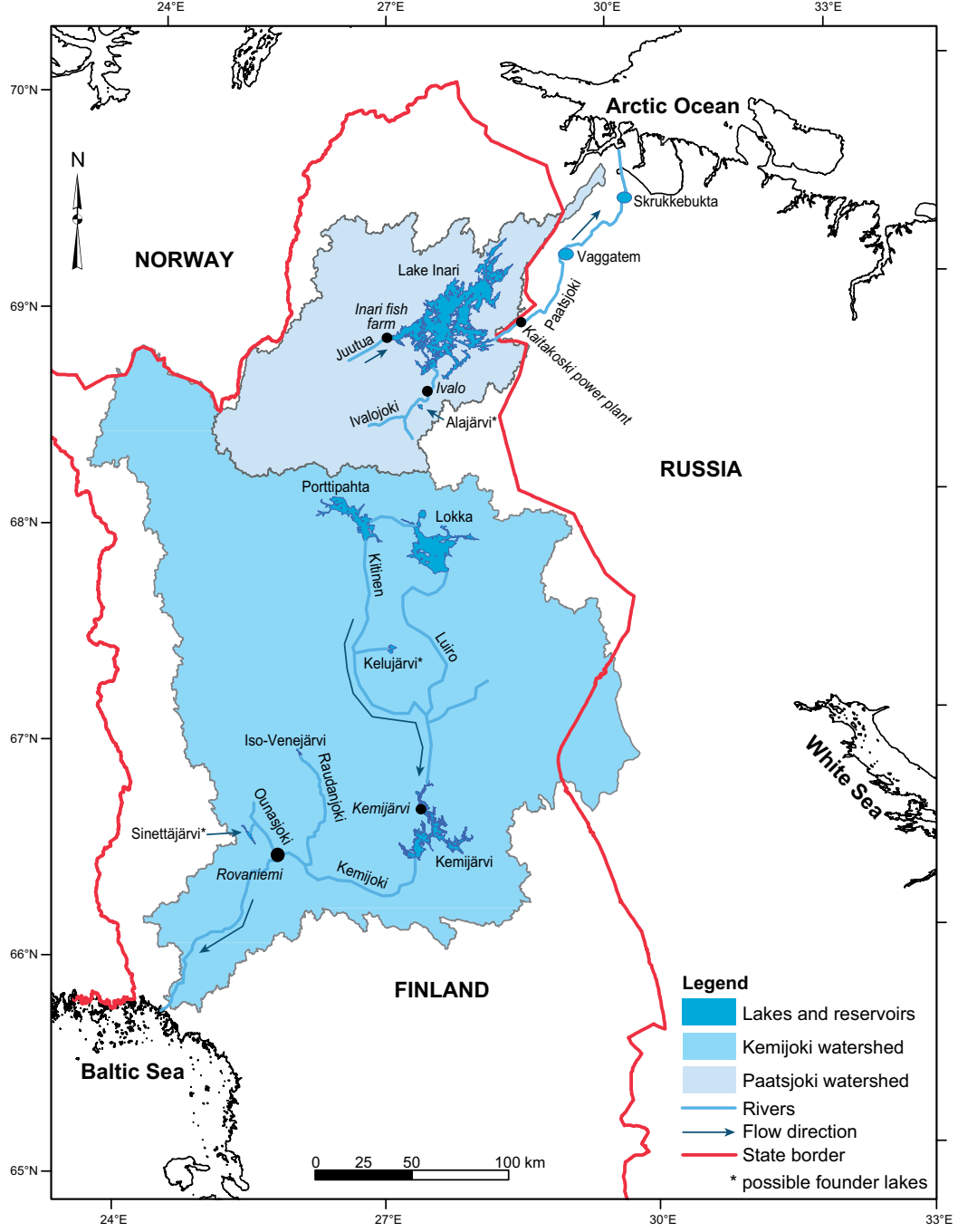

Fig. 1. Map of the study area with Lake Inari, watersheds, and possible founder lakes (Kelujärvi, Sinettäjärvi, Alajärvi) into which vendace were introduced. Data on watersheds from the Finnish Environment Institute, and on lakes and reservoirs from The National Land Survey of Finland.
Lake Inari, where vendace were observed for the first time in 1973. There, the species gradually established a new fish population in Lake Inari (Sergejeff 1985, Salonen et al. 2007), and about two decades later (between 1989 and 1995), vendace was found downstream in the Norwegian part of the Paatsjoki (Pasvik) watershed (Amundsen et al. 1999, 2012). In 2013, a genetic study confirmed that the vendace in Lake Inari and in Vaggatem and Skrukkebukta in the Pasvik watershed (Norway) were both of Sinettäjärvi origins from introduction/stocking in 1964-1966 (Praebel et al. 2013).

Between 1973 and 2021, vendace changed fisheries in Lake Inari, and became a new prey resource for predatory fishes in the lake, especially for valuable salmonids (e.g., Salmo trutta), which before vendace introduction preyed upon C. lavaretus (dwarf densely rakered whitefish; reeska in Finnish) as well as three-spined (Gasterosteus aculateus) and nine-spined (Pungitius pungitius) sticklebacks (Toivonen 1966). On the other hand, the alien vendace became quite a strong competitor for resources with native $C$. lavaretus (reeska) (Salonen et al. 2007).

Here, I describe history of the vendace in Lake Inari. The material for this work comprised yearly vendace catches and catch sample data since the mid-1980s up to the present day. 
Fig. 2. Sampled and aged vendace caught with different fishing gear in Lake Inari. Fish caught in 1986 were not analysed.

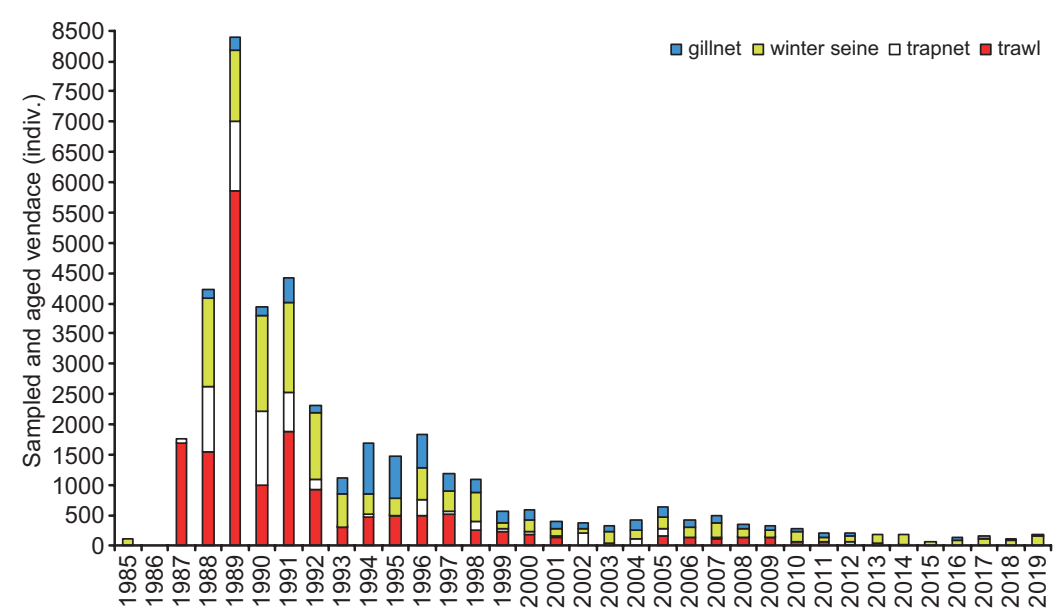

\section{Material and methods}

\section{Study area}

Lake Inari in northern Finland $\left(68^{\circ} 57^{\prime} \mathrm{N}\right.$, $27^{\circ} 40^{\prime} \mathrm{E}$ ) is a large (around $1100 \mathrm{~km}^{2}$ ) central lake in the Paatsjoki (Pasvik) watershed, draining northeast into the Arctic Ocean, first through Russia and then as a borderline watercourse between Russia and Norway (Fig. 1). The watershed has been regulated since the 1940s, and the uppermost power plant, Kaitakoski, regulates the water level of Lake Inari (annual level change $\sim 1.5 \mathrm{~m}$ ). The ice-free season in Lake Inari lasts from May-June to October-November (often December in large open-water areas). The lake is quite deep (max. depth $95 \mathrm{~m}$, mean depth $14.4 \mathrm{~m}$ ), clear and oligotrophic. Its Secchi-depth ranges from 3-4 $\mathrm{m}$ to $7-10 \mathrm{~m}$ in the southern and northern parts, respectively. The fish community includes 13 species, with whitefish (Coregonus lavaretus s.l.), brown trout (Salmo trutta), Arctic char (Salvelinus alpinus), grayling (Thymallus thymallus), perch (Perca fluviatilis), pike (Esox lucius) and burbot (Lota lota) being the most abundant native species. Minnows (Phoxinus phoxinus) are the only cyprinid species in the lake (Salonen 2004). Large obligatory stocking programmes including whitefish and piscivorous species such as brown trout and Arctic char have been carried out since the $1970 \mathrm{~s}$. In addition to vendace, two other non-native species were stocked: land-locked salmon (Salmo salar $\mathrm{m}$. sebago) until 2001 and lake trout (Salvelinus namaycush) until 2012. There are many whitefish morphs in the lake, including two dwarf forms: densely-rakered (reeska in Finnish) and sparsely-rakered (rääpys in Finnish) whitefish. They can be identified by their morphology (jaws, number of gill rakers), and they also differ from each other in their ecology (food selection and growth) (Toivonen 1966, Marttunen et al.1997).

\section{Data}

Information on the catch statistics was collected from commercial, local subsistence- and recreational fisheries with regular yearly mail inquires. These were complemented by interviews and book-keeping (daily catch and effort records) in connection with the obligatory monitoring procedures related to Lake Inari water-level regulation (see above).

Before the 1990s, during the vendace boom years, vendace samples originated from the entire Lake Inari, and afterwards mostly from the southern part of the lake. The sampling was performed mainly by commercial fishermen using gill nets, winter seines, trawls and trap nets (e.g. Salonen 1998). The data on the vendace for the 1985-2019 period include of over 40000 specimens. Especially high numbers of vendace were caught (sampled) in 1989 particularly by trawling (Fig. 2). In recent years, only around 
150 samples per year were taken from catches by winter seine and gillnets, as only these two types of fishing still targeted vendace.

The catch per unit of effort (CPUE) for vendace were calculated from the records of the commercial winter seining (1996-2020, 1-2 seine teams), and gillnet fishing (data provided by local subsistence fishermen in yearly mail inquires). Commercial fishermen caught vendace using gillnets only very occasionally, and commercial trawling had practically ceased already in the1990s after the vendace boom years. Afterwards, one or two commercial trawlers operated until 2017 , but only very occasionally (no reliable CPUE data). Starting in 1994, vendace samples taken from winter seine catches to evaluate the year-class strength.

Random subsamples (30-50 indiv.) were taken from vendace catches to determine fish total length (TL, mm), body weighed (g), as well as sex and maturity. The fish were aged mainly from scales, but as of the year 2000, otoliths were also taken from $\geq 15 \mathrm{~cm}$ TL vendace. Here, vendace growth was determined based on the actual average age-specific total length in winter seine samples taken yearly in January-April.

Based on annual catch, sample data and the age distribution according to the fishing gear used, I calculated the cumulative catch for every year-class between 1983 and 2019 (data for 2013-2019 incomplete). Only age-groups from one to seven were included because vendace older than seven years were very rare $(<5 \%)$ in every type of sampled fishing gear.

I also analysed the relationship between oneyear-old vendace caught in winter seine (CPUE of 1-year-olds) and the cumulative catch (all types of fishing gear) for 1994-2012 using linear regression.

\section{Results and discussion}

\section{Vendace introduction, current range and future}

In 1956, some vendace larvae escaped accidentally from an Inari fish farm into the Juutua River, which flows to nearby Lake Inari. In 1964-1966, vendace was introduced into nearby
Alajärvi (Fig. 1). The vendace larvae which had escaped in 1956 were from the Kelujärvi stock, and the vendace introduced in 1964-1966 were from the Sinettäjärvi stock. Both lakes are in the Kemijoki watershed (waters flow to the Baltic Sea) $150-250 \mathrm{~km}$ south of Lake Inari (Sergejeff 1985, Mutenia \& Salonen 1992) (Fig. 1). According to local accounts (J. Kyrö pers. comm.), newly hatched vendace larvae were also stocked directly into the Ivalojoki in the vicinity of the bridge in the village of Ivalo. Those larvae had the same origin (Sinettäjärvi stock) and, as the ones in Alajärvi, were also introduced in 1964-1966. The distance from Alajärvi along the Ivalojoki to Lake Inari is about $30 \mathrm{~km}$. In some way, by active swimming or drifting with the current down the river, sufficient amount of larvae managed to enter the southernmost part of Lake Inari. The first vendace were caught in Lake Inari in 1973 most likely with $15-17 \mathrm{~mm}$ (knot to knot) reeska gillnets, as before that reeska was the only species fished using such gear. In the 1980s, when the vendace fishing really began, the earlier reeska gillnets replaced by vendace gillnets and the small-scale reeska fishery transformed into a large-scale vendace fishery (Toivonen 1966; J. Kyrö pers. comm).

After the 1970s, the species gradually established a new fish population in Lake Inari (Sergejeff 1985, Salonen et al. 2007), and in the 1990s, vendace were found downstream in the Norwegian part of the Paatsjoki (Pasvik) watershed (waters flow to the Barents Sea) (Amundsen et al. 1999). In 2013, a genetic study confirmed that the vendace in Lake Inari and in Vaggatem and Skrukkebukta in the Pasvik watershed (Norway) were both of Sinettäjärvi origins from introduction/stocking in 1964-1966 (Praebel et al. 2013).On the Russian side, vendace populations are found in watersheds from which waters flow to the White and Barents Seas. Vendace in those populations may have also originated from translocations from other parts of the country (Amundsen et al. 2012).

Regulation of Lake Inari for hydroelectric power generation in Russia and Norway has continued since 1941 (Mutenia \& Salonen 1994, Marttunen et al. 1997). The water-level fluctuation in the lake is approximately $1.5 \mathrm{~m}$ (e.g. Mutenia \& Salonen 1994), which is moderate 


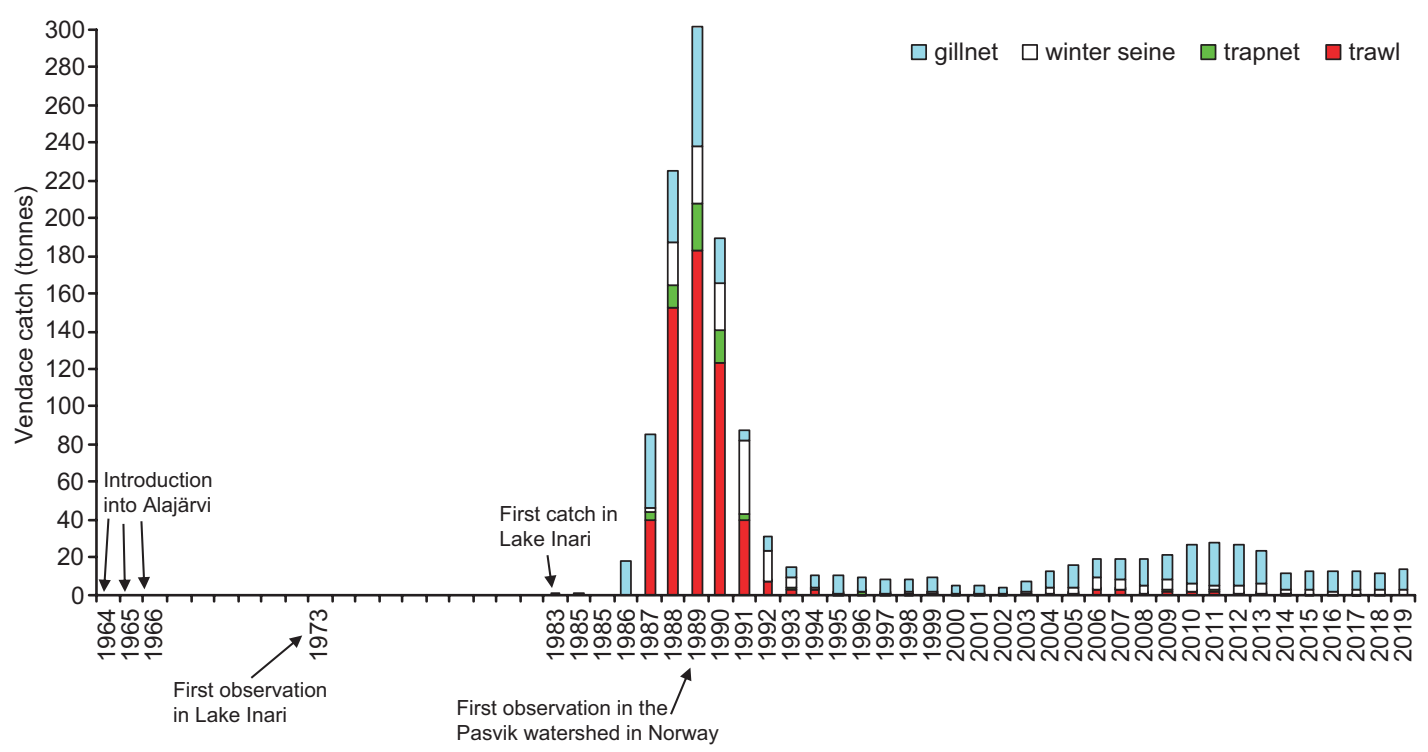

Fig. 3. Vendace catches in Lake Inari as well as years of introduction and first observations in Lake Inari and the Norwegian part of the Pasvik watershed.

compared with that in Kemijärvi, where the amplitude is seven meters. In the first decades, however, water-level changes profoundly affected fish communities and fisheries in Lake Inari. For this reason, compensatory measures, such as large-scale fish stocking of brown trout, arctic char and whitefish, were introduced. Vendace that feed on pelagic zooplankton and spawn mainly in deeper zones (1.5-30 m; Heikkilä et al. 2006, Karjalainen et al. 2021), however, seem not to be affected but detailed studies are lacking.

Introduced vendace became established in Lake Inari within about 50 years. However, if escapees from 1956 are taken into account, the species history in the lake may cover over 60 years. In Lake Inari, vendace live at the northernmost edge of their range, and outside their natural distribution area. Therefore, climate change and hydrological conditions in the lake are expected to affect this species as in Finland, the average annual mean air temperature increase for 2070-2099, compared with 19712000, has been projected to be $3-6{ }^{\circ} \mathrm{C}$ (https:// www.climatechangepost.com/finland/climatechange/). Warming will be more pronounced at higher latitudes, which will favour vendace recruitment in Lake Inari, while at more southern latitudes, similar warming may be detrimental to the species (Henttonen et al. 2017, Jeppesen et al. 2012). Thus in future, the vendace status in Lake Inari may by quite different than today.

\section{Fisheries and catches}

In the mid-1980s, trials with several new types of fishing gear - gillnets, winter seines, trap nets, and pair trawls (Mutenia \& Ahonen 1990) began, mainly targeting vendace, but also aiming at more efficient exploitation of the whitefish stocks. New methods of vendace fishing were adopted very quickly, and in the boom year of 1989 catches exceeded 300 tonnes. The bust in the 1990s after just a five-year boom period was equally rapid (Salonen 1998). Afterwards, the catches stabilized at a low level and were taken mainly using gillnets (nowadays typically 18-22 mm) (Fig. 3). CPUE by winter seining increased in 2018-2020 reaching about a $200 \mathrm{~kg}$ per haul in spring 2020 (Fig. 4). In 2010-2019, vendace CPUE in local subsistence gillnetting during the spawning period varied between 1 and $3 \mathrm{~kg}$ per net night, the best season being the autumn in 2019 (Fig. 5).

Coregonids, mainly whitefish, comprised the bulk of the Lake Inari catches during the 80 -year period. Whitefish were overwhelmingly the most 


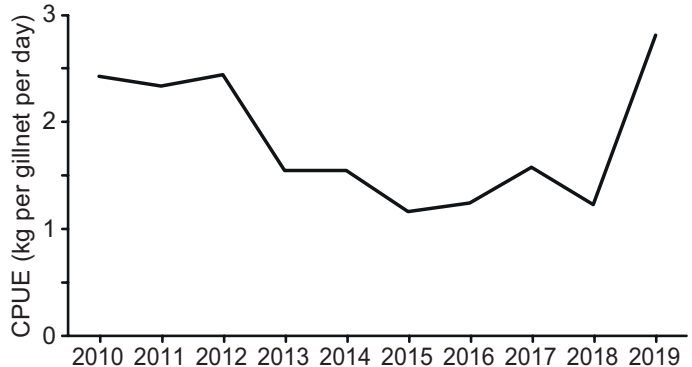

Fig. 5. Vendace gillnet fishing (18-25 mm mesh size) CPUE in Lake Inari (data obtained from local fishermen using questionnaires send by mail).

important species in 1935-1940, before the lake regulation, which started in 1941, and also in recent years, especially in 2017 and 2018 .

Salmonids (mainly brown trout), but also pike and grayling, are overall very significant and valuable species in the lake being a significant part of the fish yields (Fig. 6).

\section{Growth and age structure}

In Lake Inari, vendace growth seems to be slowing down. Until 2004, one-year-old vendace could reached nearly $95 \mathrm{~mm}$ TL, but no more than 70-80 mm after 2011 (Fig. 7). Similarly, threeyear-old vendace could reached $\sim 180 \mathrm{~mm}$ TL the mid-1990s, but no more than about $130 \mathrm{~mm}$ after the year 2014 (Fig. 7). The two-year-old vendace (data not shown) grew up to $150 \mathrm{~mm}$ TL in the mid-1990s, whereas in the most recent years, individuals were shorter than $110 \mathrm{~mm}$.
In Lake Inari, vendace individuals of around 10 years of age occur in the samples almost every year, and 13-year-old fish have also been caught (author's own data). This can be considered unusual, as there are only few lakes in Finland, where similar is observed (e.g. Lake Konnevesi; see Marjomäki et al. 2021b). Some vendace can also grow large: the two largest vendace reported from Finland weighed $550 \mathrm{~g}$ (caught on 1 October 2004, length $400 \mathrm{~mm}$ ) and $634 \mathrm{~g}$ (caught on 29 September 2020, length $399 \mathrm{~mm})$.

In Lake Inari the vendace population and catch consist of several year-classes, which should keep the catches more stable than in most lakes, where only 2-3 year-classes exist at the same time. Owing to that, one poor year-class does not affect the population as it might.

In the Norwegian part of the Paatsjoki watershed, vendace of the same origin (Sinettäjärvi) dispersed rapidly in the first decades after the first observation in 1989 (Amundsen 1999, Amundsen et al. 2012). As compared with that in Lake Inari, the population in lakes Vaggatem and Skrukkebukta grew more slowly and attained much smaller lengths. Their mortality was also higher, hence the populations consisted of much younger fish which maturated both at a younger age and at a smaller size than in Lake Inari. According to samples taken between 1991 and 2007 , in Lake Vaggatem, over $90 \%$ of the vendace at age $1+$ (length $<10 \mathrm{~cm}$ ) were sexually mature, whereas in Lake Inari, only $20 \%-40 \%$ of the vendace at age $1+$ (length $>12 \mathrm{~cm}$ ) were mature (Amundsen et al. 2012).

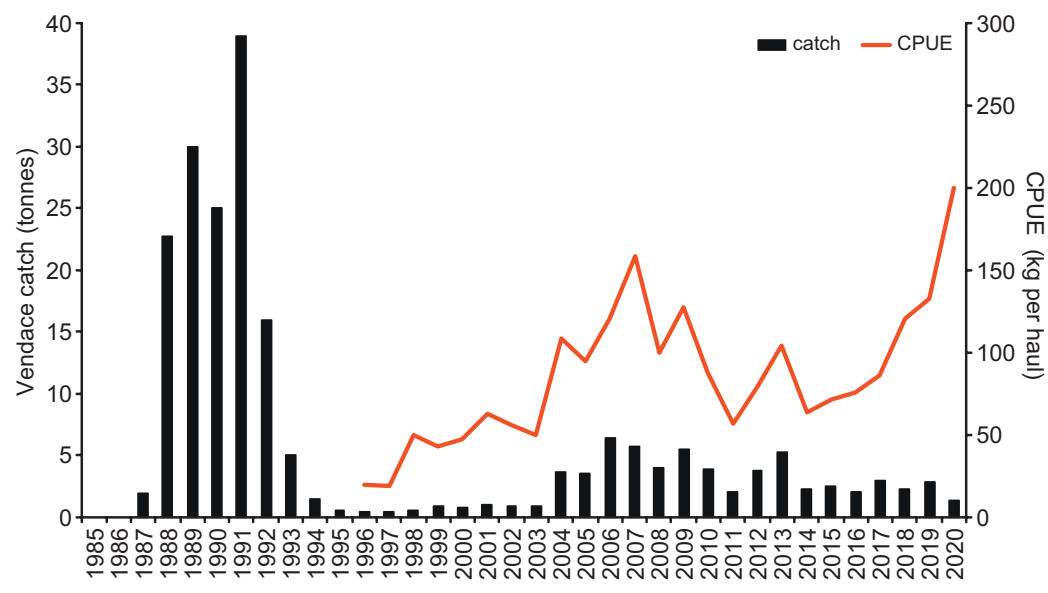

Fig. 4. Vendace winter seine catches and CPUE in Lake Inari; CPUE data from 1988-1995 are missing. At the maximum (in 1989) there were seven winter-seine teams, but no more than one at the end of the studied period (2018-2020). 


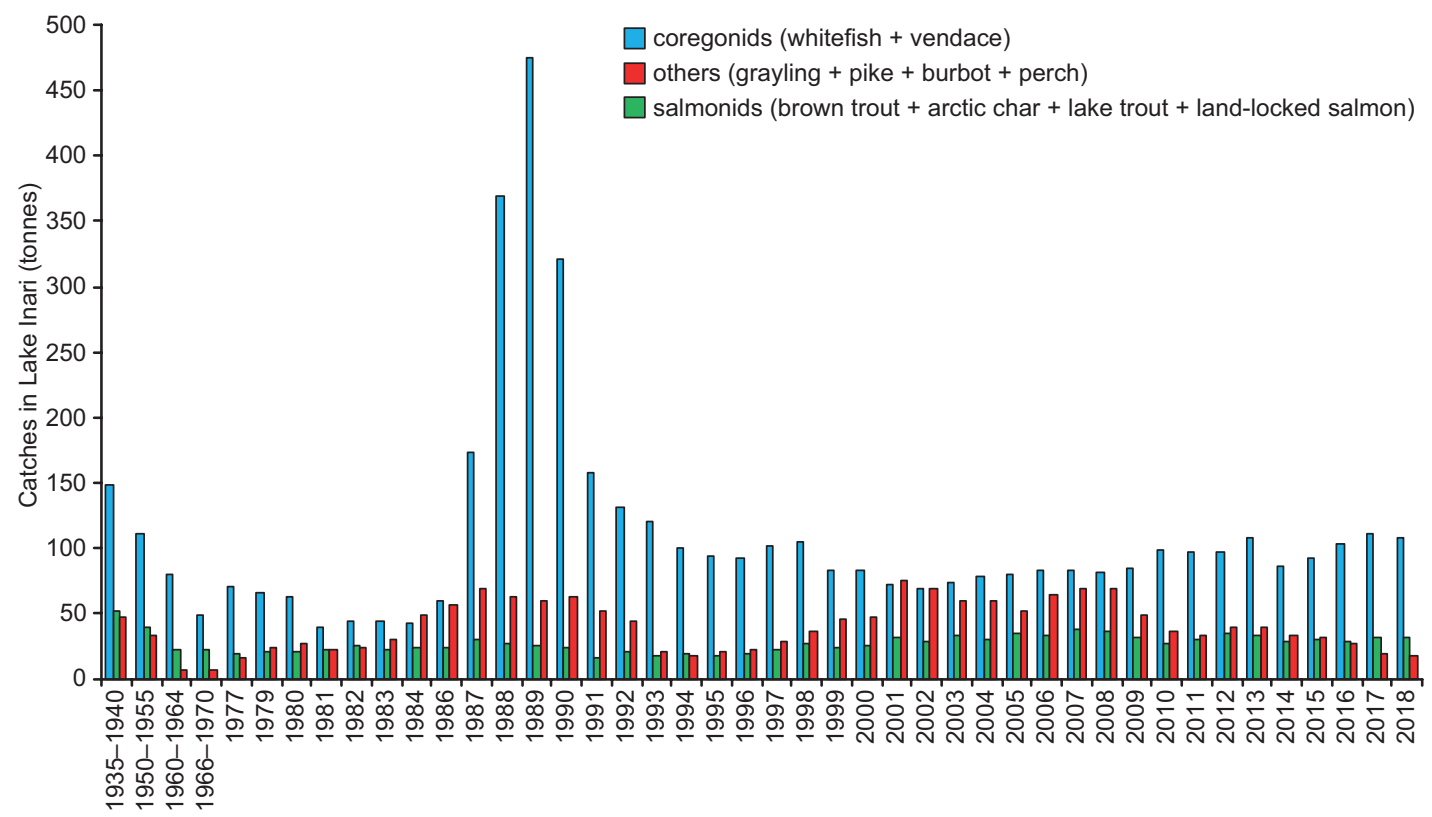

Fig. 6. Coregonid, salmonid and other fish species catches in Lake Inari. The total catch in the years 1935-1940 (before the lake regulation) equalled 250 tonnes. The highest total catch for the studied period was in the year 1989 equalled 560 tonnes. Yearly fish catches by species from Toivonen (1966, 1972), Salonen 1992 and Niva et al. (2020).

Fig. 7. Mean length $( \pm 95 \% \mathrm{CL})$ for 1-yearand 3-year-old vendace caught by winter seine fishing (January-April) in Lake Inari over the time period from 1985 to 2019.
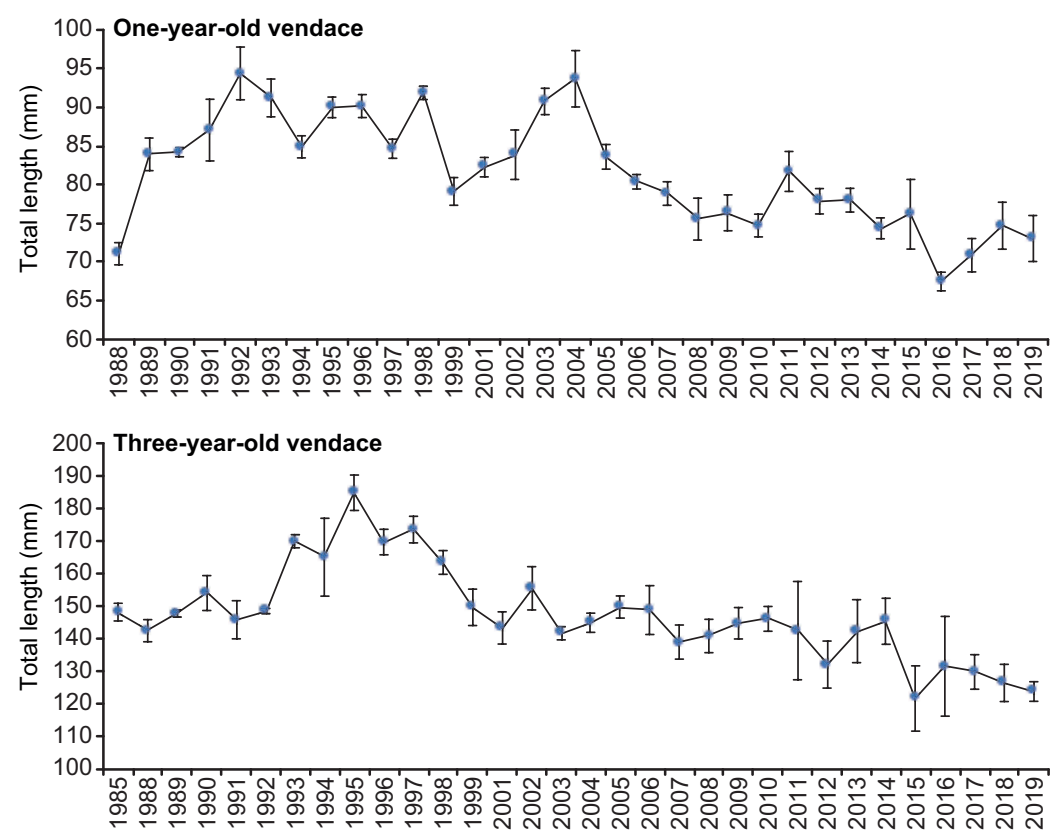

In Lake Inari, the vendace can reach a greater maximum size than elsewhere in Finland. In Iso-Venejärvi (lake in the Kemijoki watershed, $50 \mathrm{~km}$ north from Sinettäjärvi) many large vendace (700-800 g) were caught in the 1980s and 1990s. They were also rapidly growing specimens, with the oldest individuals being 7 -years old (Alanne 2004).

In Lake Vaggatem (Norway), growth of vendace declined strongly in 1995-1998 (Amund- 

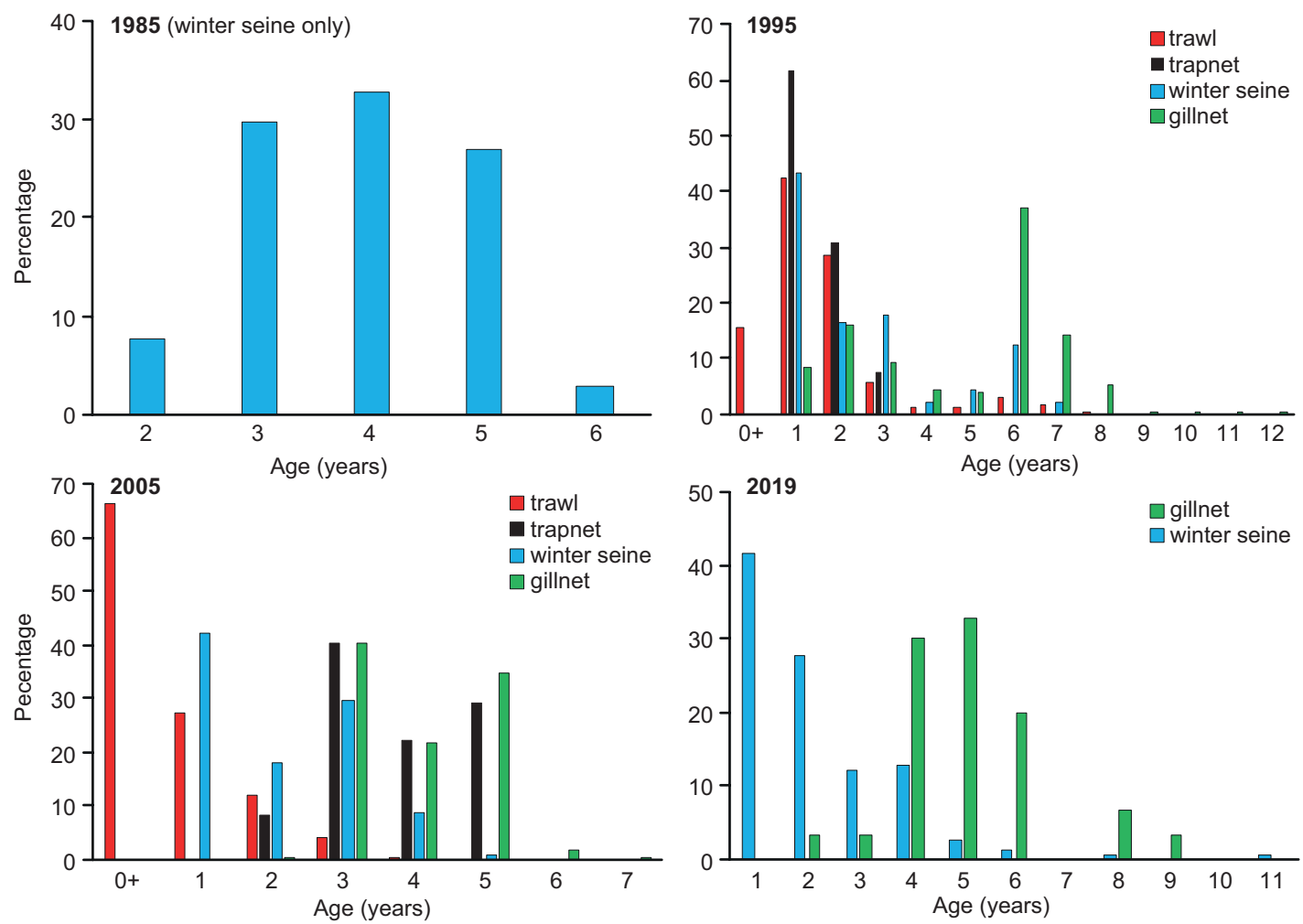

Fig. 8. Vendace age distribution in catches by different fishing gears used in Lake Inari. The samples were from the years 1985, 1995, 2005 and 2019. One-year-old vendace in winter-seine catches in 1985 catches were not analysed.

sen et al. 2012). In Lake Inari, it grew faster during the two first studied decades than in the most recent ones (age groups 1-3 based on winter seine data; Fig. 7). As growth of vendace depends on population density (see e.g. Viljanen 1986), strong vendace year-classes may grow slowly due to e.g., intense competition for limited food resources (Amundsen et al. 2012, Marjomäki et al. 2021a).

The vendace is in principle a planktivorous species. However, large individuals (about $1 \mathrm{~kg}$ weight) may be partly piscivorous. This was observed for example in Lakes Onega and Ladoga in Russia (Reshetnikov \& Lukin 2006) but not yet in Lake Inari.

\section{Year-class strength and variation}

Strong vendace year-classes appeared in the catches for many years. For example, the year- class of 1989 was still quite strong in the catches of 1995 (Fig. 8; data for 1985, 2005 and 2019 shown for comparison), and old individuals ( $\geq 7$ years old) were frequently caught with every type of fishing gear. Overall, the strongest yearclass was that of 1986, but judging from cumulative catch (Fig. 9) also those of 1989 and 1984 were very strong. Throughout the 1990s, only weak year-classes were born. Later, the yearclass 2005 produced the best catches (Fig. 9). The data from 2020 showed that the 2019 yearclass was the strongest during the 26 years of monitoring (Fig. 10).

The winter seine CPUE (one-year-old in numbers) and the cumulative vendace total catch were positively correlated (Fig. 11). The best year-class of 2005 ( 14000 recruits in the winter seine CPUE) produced cumulative catch (1-7-yearolds) of 1.6 million in the 2006-2012, whereas the weakest year-class of 1996 (only $\sim 20$ recruits in the winter seine CPUE) produced only about 0.15 
Fig. 9. Cumulative catch of vendace year-classes 1983-2012. Notice, that the year-classes of 1986 and 1989 rise above the figure scale. Data for 2013-2019 are incomplete.

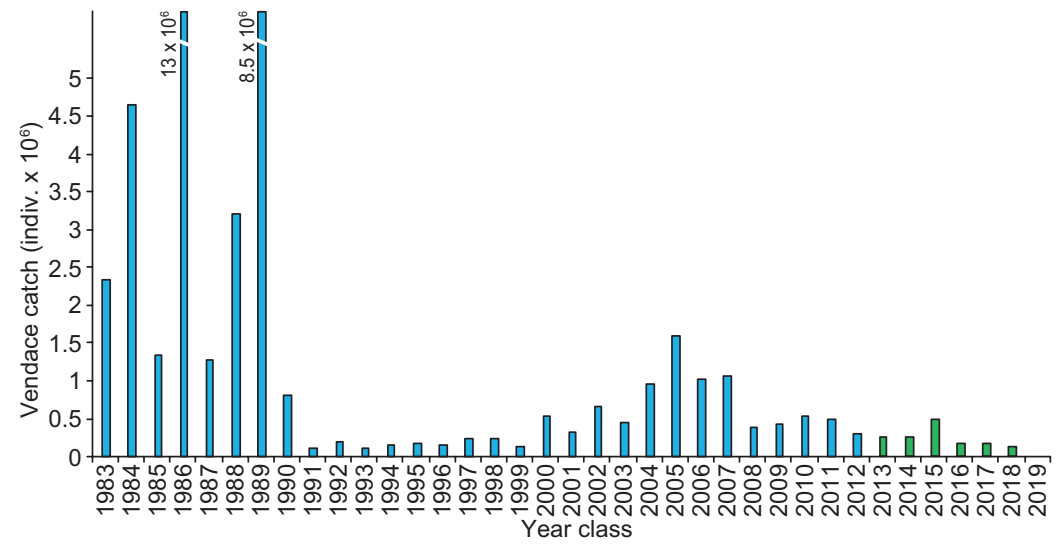

Fig. 10. Winter seining CPUE (mean $+95 \%$ CL, $n=26$ ) in the southernmost Lake Inari.

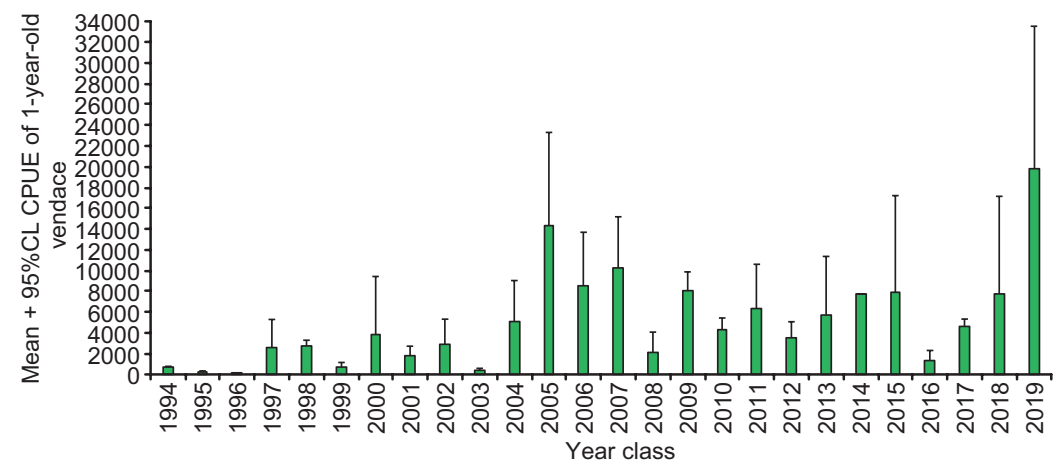

Fig. 11. Relationship between the one-yearold vendace year-class strength (caught in winter seine fishing) and vendace total catch (all year classes, all types of gear). Data from 1994-2012

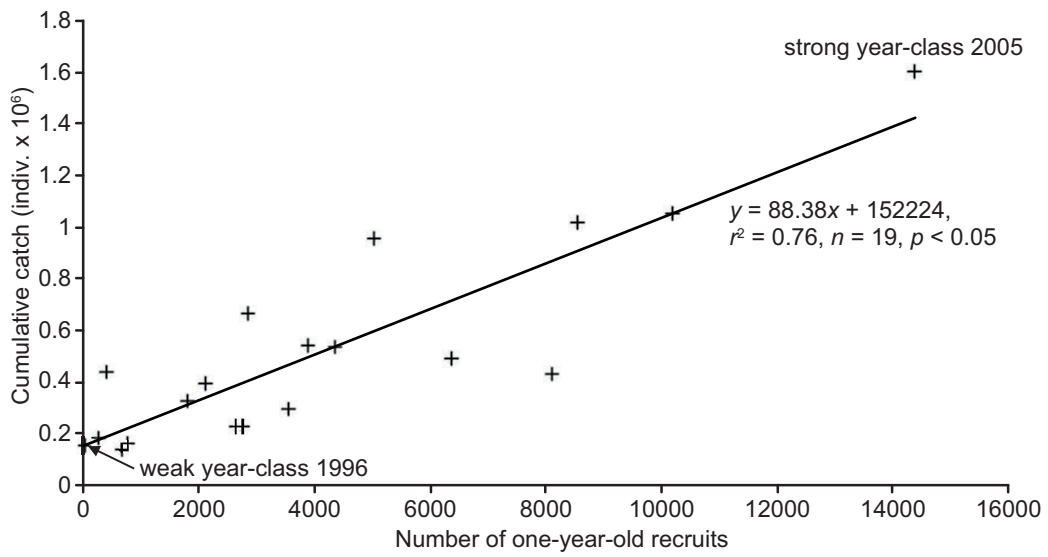

million vendace in the cumulative catch in 19972003. According to the above, it can be expected that the good year-class of 2019 may produce good catches in the future, up to the year 2025.

The vendace stock rose quite rapidly in the 1980s due to many abundant year-classes; 1983, 1984, 1986, and 1989, which remained the last strong year-class for quite a long time. Strong fluctuations are typical for vendace also in its native range (e.g. Salojärvi 1987, Auvinen 1994). In the case of Lake Inari, the reasons for this even dramatic stock variation were presumed to include unfavorable weather conditions, fishing, and salmonid predation. 
The decrease in the spawning stock in the 1990s took place at a time when the already declining stock had been subject to quite intensive fishery (Salonen 1998). However, all vendace year-classes in the 1990s were very poor and their catches were only a fraction of those when year-classes were strong (Salonen 1998). The strongest year-classes of 1986 and 1989 produced around a hundredfold more catch than the weakest ones (1991 and 1993; see Fig. 9). At the same time, the trawl fishery declined after only a few years, from 16 to 2 trawl pairs in 1989-1990 and 1996, respectively (Salonen 1998).

Due to major changes in both the vendace stock and fishing in the beginning of the 1990s, survey trawling in Lake Inari was carried out in 1993-2001, with the aim to evaluate the abundance of one-summer-old $(0+)$ vendace, the earliest life stage that could be quantified (Salonen 2004). A 12-meter-deep pelagic trawl with a cod-end mesh size of $8 \mathrm{~mm}$ was used in six areas of the lake (Nanguvuono, Ämmänhiekka, Ukonselkä, Kaikunuora, Partakko and Roiro). Until 1999, trawl CPUEs of 0+ vendace were very low, followed by slight increase in 2000 (Salonen 2004). The survey also indicated that fish densities $(0+$ and older fish) differed among the lake areas: the survey catches were much higher in the southernmost part than in the northern parts (Salonen 2004). Yearly catch statistics (author's unpubl. data) and some occasional trawl hauls along with echo sounding searches for vendace schools (J. Kyrö pers. comm.) revealed that during the short boom period in 1987-1991, vendace spread across the entire lake, but later the fish seemed to concentrate in the southern part of the lake. Our annual winter seine samples were taken from the best southernmost vendace areas of the lake.

Survey trawling for $0+$ vendace in autumn followed by winter seine sampling of one-yearold individuals (i.e., same year-class) next winter confirmed that the 2000 year-class was the first strong one for a long time (Salonen 2004).

Recent winter seine surveys revealed a very strong vendace year-class of 2019 (CPUE about 20000 recruits; Niva et al. 2020) predicting even higher catches than those of the highly productive year-class 2005 (depending on the actual fishing effort). Winter seine samples taken on 20
January and 3 February 2021 included mostly the strong vendace 2019 year-class (now twoyear-old) with some addition of the 2020 yearclass. The coming years will reveal the fate of the excellent 2019 year-class, and other potential changes in the vendace population in Lake Inari.

\section{Acknowledgements}

Greatest thanks go to professional fishermen Juha, Arvo and Olavi Kyrö who provided fish samples, and Juha Kyrö who provided catch and CPUE statistics. I also thank the staff of RKTL and LUKE who participated in the data collection and fish handling in the laboratory. Special thanks go to Ahti Mutenia (dec.) who organized the first studies of vendace, Heimo Pukkila who took care of the large-scale collection of vendace samples from the fishermen, Kirsi Leppänen who aged vendace at the end of 1980s and in the 1990s, and Sari Raineva who handled and aged vendace samples for the last 20 years.

\section{References}

Alanne, M. 2004: Iso-Venejärven muikun kasvu ja ravinnonkulutuksen arviointi bioenergeettisen mallin avulla. M.Sc. thesis, University of Jyväskylä, Finland.

Auvinen, H. 1994: Intra- and interspecific factors in the dynamics of vendace (Coregonus albula L.) populations. — Finnish Fisheries Research. 15: 49-58.

Amundsen, P.-A., Staldvik, F. J., Reshetnikov, Y. S., Kashulin, N., Lukin, A., Bøhn, T., Sandlund, O. T. \& Popova, O. A. 1999: Invasion of vendace (Coregonus albula) in a subarctic watercourse. - Biological Conservation 88: 405-413.

Amundsen, P.-A., Salonen, E., Niva, T., Gjelland, K. O., Praebel, K., Sandlund, O. T., Knudsen R. \& Bøhn, T. 2012: Invader population speeds up life history during colonization. - Biological Invasions 14: 1501-1513.

Heikkilä, J., Huuskonen, H. \& Karjalainen, J. 2006: Location of spawning grounds of vendace (Coregonus albula (L.)): implication for dispersion of newly hatched larvae. - Verhandlungen des Internationalen Verein Limnologie 29: 1725-1728.

Henttonen, H. M., Nöjd, P. \& Mäkinen, H. 2017: Environmental-induced growth changes in the Finnish forests during 1971-2010 — an analysis based on National Forest Inventory. - Forest Ecology and management 386: 22-36.

Jeppesen, E., Mehner, T., Winfield, I. J., Kangur, K., Sarvala, J., Gerdeaux, D., Rask, M., Malmquist, H. J., Holmgren, K., Volta, P., Romo, S., Eckmann, R., Sandström, A., Blanco, S., Kangur, A., Ragnarsson, S. H., Tarvainen, M., Ventelä, A.-M., Søndergaard, M., Lauridsen, T. L. \& Meerhoff, M. 2012: Impacts of climate warming on the long-term dynamics of key fish species in 24 European lakes. - Hydrobiologia 694: 1-39. 
Karjalainen, J., Tuloisela, M., Nyholm, K. \& Marjomäki, T. J. 2021: Vendace (Coregonus albula) disperse their eggs widely during spawning. - Annales Zoologici Fennici 58: 141-153.

Marjomäki, T. J., Auvinen, H., Helminen, H., Huusko, A., Huuskonen, H., Hyvärinen, P., Jurvelius, J., Sarvala, J., Valkeajärvi, P., Viljanen, M. \& Karjalainen, J. 2021a: Occurrence of two-year cyclicity, "saw-blade fluctuation", in vendace populations in Finland. - Annales Zoologici Fennici 58: 215-229.

Marjomäki, T. J., Valkeajärvi, P. \& Karjalainen, J. 2021b: Lifting the vendace, Coregonus albula, on the life table: survival, growth and reproduction in different lifestages during very high and low abundance regimes. Annales Zoologici Fennici 58: 177-189.

Marttunen, M., Hellsten, S., Puro, A., Huttula, E., Nenonen, M.-L., Järvinen, E., Salonen, E., Palomäki., Huru, H. \& Bergman, T. 1997: Inarijärven tila, käyttö ja niihin vaikuttavat tekijät. - Suomen ympäristö 58: 1-197.

Mutenia, A. \& Ahonen, M. 1990: Recent changes in the fishery on Lake Inari, Finland. - In: van Densen, W. L. T., Steinmetz, B. \& Hughes, R. H. (eds.), Management of freshwater fisheries. Proceedings of a symposium organized by the European Inland Fisheries Advisory Commission, Göteborg, Sweden, 31 May to 3 June 1988: 101-111. Pudoc, Wageningen.

Mutenia, A. \& Salonen, E. 1992: The vendace (Coregonus albula L.), a new species in the fish community and fisheries of Lake Inari. - Polish Archives of Hydrobiology 39: 583-591.

Mutenia, A. \& Salonen, E. 1994: Rehabilitation of fisheries of regulated Lake Inari, northern Finland. - In: Cowx, I. G. (ed.), Rehabilitation of freshwater fisheries: 280-288. Fishing News Books, London.

Niva, T., Salonen, E., Raineva, S., Savikko, A., Vaajala, M. \& Siitari, S. 2020: Inarijärven ja sen sivuvesistöjen kalataloudellinen velvoitetarkkailu 2019. - Luonnonvara- ja biotalouden tutkimus 107/2020: 1-44.
Praebel, K., Gjelland, K. O., Salonen, E. \& Amundsen, P.-A. 2013: Invasion genetics of vendace (Coregonus albula (L.)) in the Inari-Pasvik watercourse: revealing the origin and expansion pattern of a rapid colonization event. - Ecology and Evolution 3: 1400-1412.

Reshetnikov Y. \& Lukin A. 2006: Modern state of the diversity of Coregonids from Onega Lake and the problems of their species identification. - Journal of Ichthyology, 46: 694-708.

Salojärvi, K. 1987: Why do vendace (Coregonus albula L.) populations fluctuate? - Aqua Fennica 17: 17-26.

Salonen, 1992: Inarijärven kalataloudellinen käyttö- ja hoitosuunnitelma. Nykytila. — RKTL, kalantutkimusosasto, Helsinki.

Salonen, E. 1998: The vendace stock and fisheries in Lake Inari. - Boreal Environment Research 3: 307-319.

Salonen, E. 2004: Estimation of vendace year-class strength using different methods in the subarctic Lake Inari. Annales Zoologici Fennici 41: 249-254.

Salonen, E., Amundsen, P.-A. \& Bøhn, T. 2007: Boom and bust development by invading vendace (Coregonus albula) in the subarctic Inari-Pasvik watershed (Finland, Norway and Russia). - Advances in Limnology 60: 331-342.

Sergejeff, K. 1985: Muikku Inarijärvessä. - Suomen kalastuslehti 92: 50-51.

Toivonen, J. 1966: Lausunto veden säännöstelyn vaikutuksista Inarijärven kalakantoihin ja kalastukseen. RKTL, kalantutkimusosasto, Helsinki.

Toivonen, J. 1972: Veden säännöstelyn vaikutus Inarijärven kalakantoihin ja kalastukseen. Täydentävä lausunto. RKTL, kalantutkimusosasto, Helsinki.

Viljanen, M. 1986: Biology, propagation, exploitation and management of vendace (Coregonus albula L.) in Finland. - Archiv für Hydrobiologie Beihefte Ergebnisse der Limnologie 22: 73-97.

Williamson, M. 1996: Biological invasions. - Chapman \& Hall, London. 